\title{
Kaiso and Prognosis of Cancer in the Current Epigenetic Paradigm
}

\author{
Jaime Cofre \\ Federal University of Santa Catarina (UFSC), Molecular Embryology \\ and Cancer Laboratory, Florianopolis, SC, \\ Brazil
}

\section{Introduction}

The term cancer is used generically to represent a set of more than 100 diseases, including malignant tumors from different locations. The understanding, diagnosis and management of malignancies require scientific knowledge and experiences ranging from the knowledge of the complex epigenetic mechanisms (intracellular regulation) to the individual lifestyle choice in different societies. Therefore, cancer prevention, prognosis and control are issues of profound importance to global public health.

Cancer appears as a major public health problem both in developed and developing countries. According to the latest report from the International Agency for Research on Cancer (IARC) / WHO (Boyle \& Levin, 2008), the overall impact of cancer more than doubled in 30 years. About 12 million cancer cases and 7 million cancer deaths are estimated to have occurred in 2008. Of these, lung cancer had the greatest incidence rate (1.52 million new cases), followed by breast cancer (1.29 million cases) and colorectal cancer (1.15 million cases). Due to poor prognosis, lung cancer was the leading cause of death (1.31 million), followed by stomach cancer (780,000 deaths) and liver cancer $(699,000$ deaths About one million new cancer cases and 589,000 cancer deaths are estimated to have occurred in South America, Central America and in the Caribbean. Prostate cancer was the most common cancer in men, followed by lung, stomach and colon and rectum. Breast cancer was the most common cancer in women, followed by cancers of the cervix, colon and rectum, stomach and lung (Boyle \& Levin, 2008).

The continued population growth and ageing significantly affect the impact of cancer in the world, which is greater in developing and under-developed countries. Half of the world's new cancer cases and about two thirds of cancer deaths are estimated to have occurred in 2008 in these countries (Farmer et al., 2010). Therefore, it is essential that resources and efforts are directed towards guiding strategies for cancer prevention, diagnosis and treatment.

In this particular chapter the strategies for prevention, diagnosis and treatment in the current epigenetic scenario of the new molecular mechanisms proposed for the development of cancer will be discussed. 


\section{Epigenetics}

Epigenetics is the study of heritable changes in phenotype or gene expression caused by mechanisms other than changes in DNA sequence. The molecular mechanisms of epigenetic inheritance and its relationship with the expression of chromatin include three interrelated processes, namely DNA methylation, genomic imprinting and histone modifications (Kouzarides, 2007). Through small chemical molecules called methyl groups, which bind covalently with DNA or histones, the epigenetic processes improve the ability of genome to store and transmit biological information beyond the known structure and sequence of genetic material.

In recent years we have faced a new paradigm, a view more focused on the cell and on the search for information layers outside of the cell nucleus and even of the DNA as the center for information of the cell. These layers of epigenetic information transcend embryogenesis and cancer development processes, as follows.

\section{The embryogenesis as an epigenetic process}

The importance of epigenetics in experimental biology is decisively felt in the process of cell differentiation. The information and epigenetic marks are essential to determine which cell is phenotypically different from any other cell as a result of embryogenesis. This allows us to reprogram a somatic cell and transform it based on epigenetic principles, in a cell with characteristics of pluripotent stem cells. These cells are called ips cells (induced pluripotent stem cells)(Takahashi et al., 2007). In the Ips cells the DNA has not been changed or modified and the pluripotent state can be inherited during each cell division. This indicates that the changes in the machinery of epigenetic information, rather than genetic material, play a decisive role in controlling differentiation.

\section{The cancer as an epigenetic process}

The process of cancer development involves genomic changes identified as genetic and also changes in the epigenetic information (Jones \& Baylin, 2002; Hake et al., 2004; McGarvey et al., 2008). Altered DNA methylation patterns have been described and histone modifications in cancer cells may occur at different stages of tumor development and contribute to the development and progression of cancer (Galm et al., 2006; McGarvey et al., 2008).

Historically, the first evidence has emerged that the contribution of epigenetics to cancer development comes from nuclear transfer experiments. Nuclear transfer provides a tool for selective reprogramming of the epigenetic state of a cell genome, without changing their genetic constitution, with the purpose of assessing the role of epigenetics in tumorigenesis.

Experiments with frogs have shown that renal carcinoma nuclei can be reprogrammed to support embryonic development at the tadpole stage (McKinnell et al. 1969). Similar results were also obtained with nuclei from medulloblastoma in mice (Li et al. 2003). Therefore, the nuclei of cancer cells can be reprogrammed through a process of nuclear transfer.

Another experimental approach was also based on nuclear transfer with blastocyst formation. However, it included the creation of explants from the inner cell mass in "in vitro" culture to develop embryonic stem cell lines (Hochedlinger et al., 2004). These 
embryonic stem cells were used to confirm the origin of the tumor clone and test the initial conservation of the tumorigenic capacity of these cells originated by tumor cores. In these experiments it has been unequivocally demonstrated that the clones derived from cancer cells and that the nuclei of cancer cells (leukemia, lymphoma and breast cancer) were able to sustain the embryonic development until the preimplantation blastocyst stage. It has also been demonstrated that the oocyte cytoplasm is able to reprogram the epigenetic state of some nuclei of tumor cells, transforming these cells into pluripotent and also enabling them to sustain the differentiation of multiple somatic cell types such as melanocytes, lymphocytes and fibloblasts. Therefore, the cancer state is an epigenetic cell state susceptible of change regardless of the DNA alterations (Feinberg, 2008).

The role of epigenetics was also confirmed by studying cohorts of twins and analyzing the concordance in cancer between monozygotic and dizygotic twins, and, thus, providing information about whether family patterns are influenced by environmental or genetic patterns. If the concordance in cancer is greater between monozygotic twins (who share $100 \%$ of the genes) than between dizygotic twins (who share in average $50 \%$ of the segregated genes) the genetic effects are probably more important. On the other hand, if the concordance rate is similar in both types of twins, then the environmental effects are probably more important. Thus, the use of statistics to analyze large populations of twins allows us to estimate the magnitude of environmental and genetic effects on susceptibility to sporadic cancer.

This retrospective study has shown that hereditary factors make a minor contribution to susceptibility to most types of neoplasms, indicating that the environment plays a major role in sporadic cancer in populations living in the study areas (Lichtenstein et al., 2000). The study, on the other hand, stresses that some types of cancer, such as prostate and colorectal cancers are more influenced by genetic factors than previously thought.

Thus, even more important aspects related to diseases are being reworked, and cancer may no longer be categorized as a disease based on genetics alone, and all the data indicate that most commonly diagnosed cancers in the world have primarily environmental or epigenetic origin. Except for some types of cancer considered hereditary, familial adenomatous polyposis, colorectal cancer and prostate cancer, the contribution of hereditary factors to the development of cancer is thought to be relatively small.

\section{How the epigenetics affects genetics}

The DNA methylation takes place only at cytosine bases that are located $5^{\prime}$ to a guanosine in a CpG dinucleotide. This dinucleotide is actually underrepresented in the genome, but short regions, known as $\mathrm{CpG}$ islands, are rich in $\mathrm{CpG}$ content. Most $\mathrm{CpG}$ islands are found in the proximal promoter regions of almost half of the genes in the mammalian genome and are, generally, unmethylated in normal cells. In cancer, however, the hypermethylation of these promoter regions is now the most well categorized epigenetic change to occur in tumours, it is found in virtually every type of human neoplasm and is associated with the inappropriate transcriptional silencing of genes, involving tumour-suppressor genes.

These tumour suppressor genes are predicted to be important for tumorigenesis, but seem not to be frequently mutated and de novo hypermethylation of $\mathrm{CpG}$ islands in the promoters of MLH1 (mutL homologue 1, colon cancer, non-polyposis type 2) (Herman et al., 1998) and 


\begin{tabular}{|c|c|c|c|}
\hline Author & Organ/tissue & \begin{tabular}{|c|}
$\begin{array}{c}\text { Genes } \\
\text { studied }\end{array}$ \\
\end{tabular} & \begin{tabular}{|c}
$\begin{array}{c}\text { Altered genes-aberrant methylation-aberrant } \\
\text { Distribution }(\mathrm{p})\end{array}$ \\
\end{tabular} \\
\hline Herman et al., 1995 & Many Cancers & p16 & p16 - Hypermethylation (the first evidence) \\
\hline Herman et al., 1998 & Colorectal & hMLH1 & hMLH1-Hypermethylation $(\mathrm{p}<.001)$ \\
\hline Esteller et al., 2000 & Breast, Ovary & BRCA1 & BRCA1- Hypermethylation $(\mathrm{p}<.0002)$ \\
\hline Esteller et al., 2000 & Colorectal & hMGMT & MGMT (k-RAS)-Hypermethylation $(\mathrm{p}=.002)$ \\
\hline Cho et al., 2003 & Stomach & CAGE & CAGE- Hypomethylation \\
\hline Russo et al., 2005 & Lung/Blood & p16/DAPK & p16/DAPK - Hypermethylation $(\mathrm{p}=.001)$ \\
\hline Sinha et al., 2009 & Tongue & p16 & p16- Hypermethylation $(\mathrm{p}=.0361)$ \\
\hline $\begin{array}{l}\text { Tanemura et al., } \\
2009\end{array}$ & Skin & RASSF1A & RASSF1A- Hypermethylation $(\mathrm{p}<.005)$ \\
\hline Daí et al., 2009 & Lung & Kaiso & $\begin{array}{l}\text { kaiso- Cyoplasmic distribution }(\mathrm{p}=.005) \\
\text { Hypermethylation- } 16(\mathrm{p}<.0001) \text { MINT31 }\end{array}$ \\
\hline Kim et al., 2010 & Intestine & p16/MINT31 & $(\mathrm{p}<.004)$ \\
\hline Muggerud t al., 2010 & Breast & RASSF1A & RASSF1A- Hypermethylation $(\mathrm{p}<.001)$ \\
\hline Taghavi et al., 2010 & Esophagus & p16 & p16 - Hypermethylation $(\mathrm{p}<.001)$ \\
\hline
\end{tabular}

Table 1. Summary of epigenetic modifications associated with human cancers (prospective and retrospective studies).

MGMT (O6-methylguanine-DNA methyltransferase) (Esteller et al., 2000b), seems to be that leads to their inactivation. Hypermethylation of the promoter of MLH1 can lead to microsatellite instability, and hypermethylation of the promoter of MGMT leads to increased $\mathrm{G} \rightarrow \mathrm{A}$ transitions. Additionally, there is a growing list, of other tumour suppressor genes in which promoter hypermethylation is the only mechanism for the loss of function of these genes in tumorigenesis: breast cancer 1, early onset (BRCA1) (Esteller et al., 2000a), von Hippel-Lindau syndrome (VHL)(Herman et al., 1994), p16 (Herman et al., 1995; Russo et al., 2005; Sinha et al., 2009; Kim et al., 2010; Taghavi et al., 2010), death associate protein (DAP) kinase 1 (DAPK1) (Russo et al., 2005), and RASSF1A (Tanemura et al., 2009; Muggerud et al., 2010), which encodes a protein of unknown function that can bind to the RAS oncogene (Table 1).

The epigenetic modifications can also be induced by environmental and occupational exposures thus contributing to carcinogenesis. A good example is the methylation changing the absorption wavelength of cytosine, into the range of incident sunlight, resulting in CC $\rightarrow$ TT mutations, which commonly occur in skin cancers (Pfeifer et al., 2000). So, tobacco smoke has been estimated to account for $30 \%$ of all cancer deaths and $85 \%$ of lung cancer deaths due to the presence of thousands of mutagenic compounds, including polycyclic aromatic hydrocarbons and nitrosamines. In this case, methylated CpGs are also preferred binding sites for benzo(a)pyrene diol epoxide and other carcinogens that are found in tobacco smoke (Yoon et al., 2001). These cause DNA adducts and G $\rightarrow T$ transversion mutations, which are often found in the aerodigestive tumours of smokers (Ziech et al., 2010). On the other hand, one of the most well established occupational carcinogenic agents is asbestos along with a growing list of tumorigenic agents that include: wood-dust particulates, solvents, paints, dye products, gasoline, petroleum-based mixtures, benzenes, mineral oils, phthalates and metal ions (Ziech et al., 2010). For these agents, the free radicalinduced damage is suggested to be involved in aberrant epigenetic changes observed during the carcinogenic process. The understanding of epigenetic alterations has become clearer the mechanism by which lifestyle choice like smoking and drinking, diet, environment and infections affecting the DNA tissue-specific cells and altering the behavior of cells in this tissue. 
Finally, besides DNA hypermethylation, cancer cells have also been shown to undergo dramatic global hypomethylation (Ehrlich, 2002; Cho et al., 2003) and changes in the organization of the histone protein complex that would serve as epigenetic biomarkers indicative of the carcinogenic process (He and Lehming, 2003). Many references in the literature published in the last years reviewed the importance of alterations in DNA methylation and histone modifications for better cancer diagnostics and therapeutic strategies (Jones and Baylin, 2002; Ziech et al., 2010; table 1). Further review of this subject is not within the scope of this chapter, which is aimed to show the role of proteins, like Kaiso, which interact with methylated DNA and participate in the establishment of cancer, as we shall see later in this chapter.

\section{The epigenetics and proteomics walking together toward the diagnosis and prognosis of cancer, in the current epigenetic context}

A major challenge faced by cancer therapy is to be able to predict the early stage of the disease in order to provide an appropriate treatment for the patient (Ludwig and Weinstein, 2005). In this regard, the molecular biomarkers have been useful for distinguishing different subtypes of patients with different clinical profiles and at all stages of disease, expanding our prognostic ability (Seligson et al., 2005).

Over the past decades high-throughput technologies including genomics, epigenome, transcriptome and proteomics have been applied to improve our understanding of cancer pathogenesis in order to develop strategies aimed to improve cancer treatment (Seligson, 2005; Ocak et al., 2009). The ultimate goal of these technologies is to help develop noninvasive methods for specific and sensitive diagnosis and facilitate prediction of the response of a patient to a given therapy, as well as help identify potential therapeutic targets (Ueda et al., 2011).

The most important technologies used in the study of cancer are proteomics and epigenomics that help understand that cancer cell phenotype is primarily determined by proteins, and, thus, a genomic or transcriptome approach of the disease are extremely limited. This can be said because it is known that $i$. levels and protein expression have a low correlation with mRNA levels, ii. proteins undergo post-translational modifications that may alter its function, iii. in the same cell can express different proteins using a mechanism of differential splicing from the same mRNA and very important as we shall see iv. the same protein may have a different function depending on the cellular compartment where it is located. Therefore, the protein detection techniques, including immunohistochemistry (IMH), in this new context, are of vital importance for understanding cellular processes and disease emergence.

In order to better understand the cancer cell and the development of cancer, proteomic information projects have been created based on epigenetics in which proteins and their interactions with the epigenome inside the cell become the key aspect in the understanding of how cancer cells work (Stefanska et al., 2011; Jerónimo et al., 2011). Therefore, knowledge of machinery and all the protein interactions established by them may be important for the prognosis of the tumor and the development of a proper drug to fight cancer and to determine the mechanisms of the disease. 
A good example is the study of the proteins of the methyl-CpG-binding domain (MBD) that "read" and interpret the signals in DNA methylation and are critical mediators of various epigenetic processes. We currently know that the family of MBD proteins is formed by five MBD1 and MeCP2 -4 members. There is also a member of non-classical MBD protein called Kaiso that uses a "zinc finger" domain to bind to methylated DNA and mediate transcriptional repression. The factor Kaiso and its partner p120ctn are considered similar to the $\beta$-catenin-TCF/LEF (T-cell factor / Lymphoid Enhancing factor) pair that regulate genes of canonical Wnt pathways, with the peculiarity that Kaiso (the difference in TCF/LEF) can interact with the epigenome in cancer development. As usually, hypermethylation is a recognized gene silencing mechanism in processes of tumorigenesis and drug resistance. Obviously, the MBD protein and Kaiso could be important modulators of tumorigenesis and excellent therapeutic targets for developing anti-cancer therapies (Sansom et el., 2007). Therefore, the role of protein detection methods in the diagnosis, prognosis and even in the development of therapies against cancer is unquestionable in the current epigenetic scenery of disease etiology (Yoshimura et al., 2011).

\section{The multifunctional protein and its relation to cellular compartments}

A single protein can have different functions in a cell and these functions concern the compartment where they are located. One of the best documented examples is that transglutaminase 2 (TG2) may act as a transglutaminase, G-protein kinase, protein disulfide isomerase or as an adapter protein. These multiple biochemical activities are involved in a wide variety of cellular processes such as differentiation, cell death, inflammation, cell migration and others. The specific microhabitats and subcellular compartments of location of the plasma membrane, cytoplasm, nucleus, mitochondria, or extracellular space are important in the development of different biochemical activities by the same protein structure (Park et al., 2010).

Thus, in our search for a drug target, e.g., cancer, we must always know the location of a given protein in the cell and be aware of how this cell places these proteins in different micro environments, and that more often than not these different functions may occur simultaneously. So part of the strategy to find the correct pharmacological targets is the previous understanding of the structure and the establishment of subcellular microenvironments inside the cells and the better knowledge of the complex and dynamic subcellular compartmentalization that will be further explained.

Therefore, immunohistochemistry provides information that cannot be obtained in any other way, which is the relationship between the pathological state and the dimension of the altered compartment (Oliver and Jamur, 2009; Dabbs, 2010), of great relevance to the establishment of the cancer diagnosis, as we shall see soon.

\section{The multifunctional proteins, compartments and cancer}

Surprisingly, over the past few decades multifunctional proteins provided the basis of the study of some diseases, including cancer. Alterations and aberrations of the multifunctional proteins regarding their distribution and subcellular localization have been used to diagnose the pathological state. I will consider briefly connexins, $\beta$-catenin and kaiso as examples of these proteins and their role in cancer development. 


\section{Connexins}

Connexins can be channels of intercellular communication or proteins that trigger processes of proliferation or apoptosis, depending on the cellular context (Goodenough \& Paul, 2003).

Traditionally, it was believed that the role of connexins in cancer development was related to its role in intercellular communication channel or gap junctional intercellular communication activity (GJIC). In fact, cancer was the first disease to be associated with connexin disorders (Loewenstein, 1979). The evidence was mainly related to the use of tumor-promoting agents (non-mutagenic carcinogens) and mitogens that decreased the activity of connexin-mediated intercellular communication (Budunova \& Williams, 1994) and, on the other hand, antineoplastic agents or chemicals promoting cell coupling through these proteins (King \& Bertram, 2005). It was also shown that tumor-derived cells were deficient in expression of connexins (Lee et al., 1992; Laird et al., 1999) and that studies of overexpression of these proteins showed decrease in cellular proliferation (Yamasaki \& Naus, 1996). This created a favorable scenario that could lead one to believe that the decrease in expression of connexins and, thus, intercellular communication, was related to cell proliferation and tumor progression.

The most important work on the change in concepts regarding these channels of communication was the transfection of connexin 43 that makes it possible reversing the neoplastic phenotype of a strain of human glioblastoma cells and that showed that phenotypic reversion was associated with a cytoplasmic localization of connexins without increasing the ability to establish intercellular communication between cells (Huang et al, 1998). Therefore, a new concept has arisen, according to which connexins could have two different functions not necessarily connected: (i) intercellular communication in the plasma membrane and (ii) direct modulation of cell growth control in cell cytoplasm.

Concerning the connexin role in regulating cell proliferation, two hypotheses have been developed: 1) a downregulation of connexins from the plasma membrane is an indirect result of the activation of MAPK (mitogen-activated protein kinase) and Akt (phosphoinositide-activated kinase) and 2) they act as negative regulators of intercellular junctions (Kojima et al., 2004). However, other lines of evidence indicated that the connexins were directly involved in the regulation of cell growth and that its downregulation would contribute to (and not be a consequence of) the loss of cell cycle control (Vinken et al., 2006).

A detailed study supporting this latter idea used transfection of connexin 43 in human osteosarcoma cells, which inhibited cell proliferation without restoring intercellular communication (Zhang et al., 2001). In this model direct connexin 43 changes the expression of p27/Kip1 (the cyclin-dependent kinase inhibitor). Importantly, Cx43, or at least the carboxy terminal tail of this protein has been localized within the nucleus with the use of immunohistochemistry, confirming an intracellular regulatory role (Dang et al., 2003; Cofre \& Abdelhay, 2007).

In primary breast tumors, immunohistochemistry can clearly detect the cytoplasmic expression of connexins 43 and 26, being a commonly used diagnostic test for this stage of the disease (Kanczuga-koda et al., 2006). However, immunohistochemistry shows that in the same metastatic tumor cells taken from the lymph node, the expression of connexin 43 and 26 changes and has now expanded, though in the plasma membrane. This increased expression in the cell membrane is considered the earliest event in the process of metastasis 
(Kanczuga-koda et al., 2006). The important diagnostic value of IMH is evident in the resolution stage of the disease.

Although the role of connexins in the process of metastasis is controversial because some studies indicate that connexin expression is inversely proportional to metastatic capacity of a primary tumor (Nicolson et al., 1988), other studies reveal that connexins might be involved in metastasis (Carystinos et al., 2001).

At least it is clear that, unlike previously thought, connexins have a tumor suppressor function, but not from a classical point of view, since there are no mutations of this protein associated with carcinogenesis. So, they seem to have different effects on different stages of carcinogenesis, (depending on the connexin isoform or cell type in which it is expressed). Connexins seem to favor cell proliferation when they are downregulated (cytoplasmic localization) and increase the potential for invasion and metastasis when they are overexpressed (initially in the plasma membrane) (for a review of this literature sees Crespin et al., 2008). As we shall see at the end of this chapter, this issue needs to be clarified for a better understanding of subcellular compartmentalization and mechanisms of regulation of intracellular signaling.

\section{0. $\beta$-catenin}

The decisive factor in paradigm change regarding proteins with various compartments inside the cell and its relationship with the processes of disease establishment was $\beta$-catenin. The protein $\beta$-catenin is a transcriptional factor with nuclear function and also a structural component of tight junctions (adherens junctions) in the plasma membranes of the cell. The role of cell adhesion was the first to be characterized and such role is possible because $\beta$ catenin interacts with cadherins and with the actin cytoskeleton via an adapter protein acatenin (Kemler, 1993)(Figure 1a). The transcriptional function developed as part of the intracellular pathways of the canonical Wnt. In the nucleus $\beta$-catenin acts as a cofactor along with TCF/LEF in the upregulation of a variety of oncogenes including cyclin D1 and c-myc (Figure 1d). The canonical Wnt/Wingless signaling pathway plays an important role in embryonic development and tumorigenesis (Morin, 1999; Polakis, 2000; Bienz, 2005).

The transcriptional role of $\beta$-catenin is very interesting because it involves translocation from the cytoplasm to the nucleus and initiates the expression of its target genes within it (Nusse, 1997; Akiyama, 2000). In the absence of Wnt binding a macromolecular complex formed by the cytoplasmic protein APC (adenomatous polyposis coli), Axin and disheveled (DSH) stimulate the phosphorylation of $\beta$-catenin. Directly responsible for this phosphorylation is the protein casein kinase 1 (CK1) and glycogen synthase kinase 3 (GSK3). B-catenin phosphorylated is destined to a ubiquitin-mediated degradation of $\beta$-catenin (Figure $1 \mathrm{~b}$ ). So, in the absence of Wnt signaling levels of $\beta$-catenin are kept low by the action of Gsk3 and CK1 (Clevers, 2006; McDonald et al., 2009).

Translocation of $\beta$-catenin only happens when the receptors of the canonical Wnt pathways are activated and the macromolecular complex is recruited to the plasma membrane proteins with CK1 and GSK3 and thus could not phosphorylate $\beta$-catenin (Figure $1 \mathrm{c}$ ). The key point in this model is that the activation of canonical pathway leads to stabilization of $\beta$ catenin. Therefore, Wnt signaling would finally prevent $\beta$-catenin degradation, which could then translocate to the nucleus and perform its transcriptional activity (Clevers, 2006). As we 
shall see later, this classical interpretation may change when additional information on subcellular compartmentalization is gained.

In clinical practice aberrant changes in the expression of $\beta$-catenin in the nucleus have made it possible to suggest the use of this molecule as a complement to the differential diagnosis of various cancers, including cancers of the gastrointestinal tract, lung and tumors of gynecological origin (Montgomery \& Folpe, 2005). Also, the absence or loss of nuclear expression of $\beta$-catenin expression associated with strong cytoplasmic P-cadherin was associated with melanoma aggressiveness and poor patient survival, establishing an important prognostic value in these types of cancer for $\beta$-catenin (Bachmann et al., 2005).

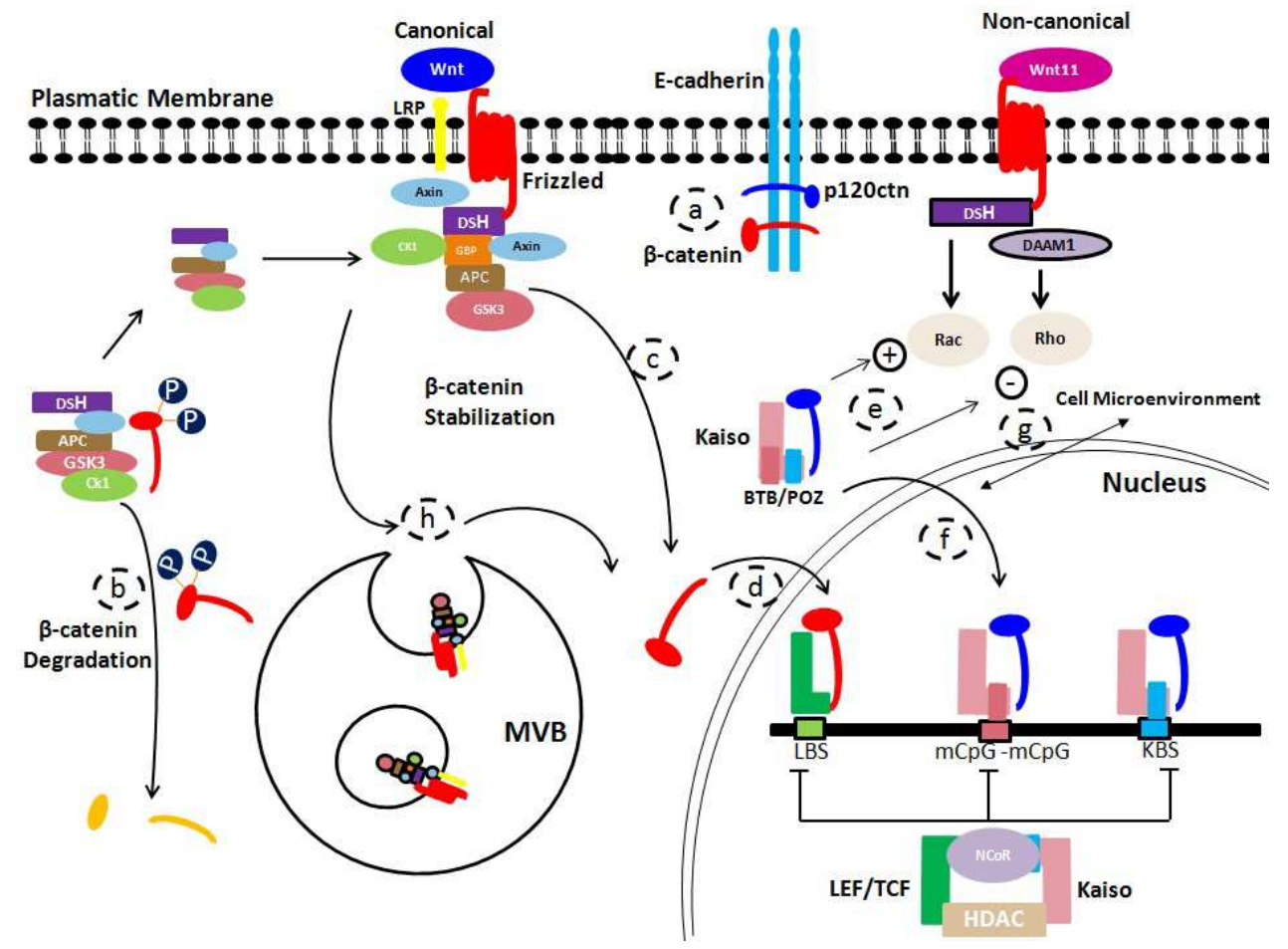

Fig. 1. Canonical and non-canonical Wnt signaling pathway. Crosstalk between Kaiso, Kaiso-p120ctn, $\beta$-catenin and Endossomal compartments. a. In the absence of Wnt ligands or in the case of high E-cadherin concentrations, $\beta$-catenin and p120ctn associate with Ecadherin, promoting intercellular adhesion. b. In the absence of Wnt binding, a macromolecular complex formed by the cytoplasmic protein APC (adenomatous polyposis coli), Axin and disheveled (DSH) stimulate the phosphorylation of $\beta$-catenin. Directly responsible for this phosphorylation is the protein casein kinase 1 (CK1) and glycogen synthase kinase 3 (GSK3). B-catenin phosphorylated is destined to a ubiquitin-mediated degradation of $\beta$-catenin. c. The activation of canonical pathway leads to stabilization of $\beta$ catenin. Therefore, Wnt signaling would finally prevent $\beta$-catenin degradation, which could then (d.) translocate to the nucleus, and perform its transcriptional activity, associate with lymphoid enhancer-binding protein (LEF)/T-cell factor (TCF). e. If E-cadherin is mutated or 
downregulated, p120ctn become at least partly cytoplasmic. Cytoplasmic p120ctn is stable and modulates small GTPases by stimulating RAC and inhibiting RHO. Both small GTPases are stimulated by non-canonical Wnt signalling. f. Kaiso translocate into the nucleus and within the nucleus kaiso associates with co-repressors $(\mathrm{N}-\mathrm{CoR})$ and histone deacetylases (HDAC) and represses genes harbouring KBS (Kaiso-binding sites) or methylated CpG $(\mathrm{mCpG})$ islands in their regulatory domain. Likewise, a NCoR complex with lymphoid enhancer-binding protein (LEF)/T-cell factor (TCF) represses genes with a LEF binding sequence (LBS). g. Translocation of Kaiso in the nucleus and vice versa is mainly under the influence of microenvironmental factors. $h$. The protein complexes involving the Wnt receptor, Gsk3 and CK1 (among others), are then taken inside the lumen of the multivesicular bodies (MVBs), separating Gsk3 from their cytoplasmic substrates and it also produces the stabilization of $\beta$-catenin. APC, adenometous polyposis coli protein; $\mathrm{BTB} / \mathrm{POZ}$, broad-complex, tramtrak and bric-a-brac/poxvirus and zinc finger domain; DAAM1, Dishevelled-associated activator of morphogenesis 1; GBP, GSK3-binding protein; LRP, LDL-receptor-related protein (Wnt co-receptor). Wnt signalling pathway modified from Van Roy \& McCrea, 2005.

\section{Kaiso}

This protein has been recently considered revolutionary due to its multifunctional role, modulating cytoplasmic processes and fulfilling transcriptional functions. It has the specific ability to interact with methylated DNA configuring an interesting pharmacological target for molecules that participate in the interphase of the epigenome. It is also known to be decisive in the process of tumorigenesis, and cytoplasmic accumulation of this protein, such as detection by IMH, plays an important role in the prognosis of some cancers. Because of these important reasons, the impact produced by this protein in a new scenario in epigenetic cancer shall deserve greater consideration.

Kaiso protein (encoded by the zinc finger and broad-complex, tramtrack and bric-a-brac (BTB)-domain-containing 33 gene ZBTB33) is a transcriptional factor that has a BTB/POX domain for the protein-protein interaction in the amino-terminal portion and a "Zinc Finger" domain for interaction with DNA in the carboxyl-terminal portion (Collins et al., 2001; Daniel \& Reynolds, 1999). Due to the aforementioned characteristics Kaiso is member of a subfamily of "zinc finger" proteins known as POZ-ZF (Daniel \& Reynolds, 1999). Most members of this subfamily (POZ-ZF) transcriptional factors including, Kaiso, BCL-6, PLZF, HIC-1, FAZF, APM1, MIZ-1, ZBTB7 and champignon are involved in the process of cancer development (Bardwell \& Treisman, 1994; Albagli et al., 1995; Wales et al., 1995; Schneider et al., 1997; Reuter et al., 1998; Hoatlin et al., 1999; Maeda et al., 2005a).

Kaiso protein interacts specifically with p120 catenin (p120ctn), a member of the armadillo family that owns $\beta$-catenin (Daniel \& Reynolds, 1999). $\beta$-catenin and p120ctn are very similar molecules possessing the two i. domains of interaction with the cytosolic portion of cadherins and ii. the ability to translocate from the cytoplasm to the nucleus (Reynolds \& Roczniak-Ferguson, 2004). A p120ctn is a regulator of the kaiso function and it is known that in the nucleus of the cell they directly modulate the action of canonical Wnt pathways and target genes of $\beta$-catenin, which is another indication of the importance of Kaiso in the development of cancer (Daniel, 2007). 
The genes transcriptionally regulated by Kaiso are matrilysin (Spring et al., 2005), c-myc and cyclin D1 (Van Roy \& McCrea, 2005), all of them widely known for their involvement in cell proliferation and metastasis and all also regulated by the domain "Zinc finger" of Kaiso (Daniel, 2007). Gene Wnt11 is another important and well- known regulatory target, which belongs to the non-canonical Wnt pathways (Kim et al., 2004).

The non-canonical Wnt pathways are involved in cell polarity and cell movements of epithelial-mesenchymal transition observed during gastrulation, and also during the process of metastasis (Wallingford et al., 2002; Veeman et al., 2003). The cytoplasmic molecules involved in the transduction of non-canonical Wnt pathway are DSH (Dishevelled) and DAAM1 (Dishevelled-associated activator of morphogenesis 1) (Habas et al., 2001) that through two independent and parallel pathways lead to activation of GTPases, Rho (Marlow et al., 2002; Habas et al., 2001) and Rac (Habas et al., 2003)(Figure 1 e). Ultimately, the activation of a kinase assorted to the Rho called ROCK would be responsible for the reorganization of the cytoskeleton (Veeman et al., 2003). p120ctn regulates the cell cytoplasm proteins Rho and Rac (Van Roy \& McCrea, 2005) and Kaiso would be indirectly related to processes that involve reorganization of the cytoskeleton during metastasis.

The Kaiso protein, unlike other members of the subfamily, appears to be the only factor with bimodal features in their interaction with DNA, being able to interact specifically with methylated CpG island sites and with consensus DNA sequences CTGCNA (Prokhortchouk et al., 2001; Daniel et al., 2002) (Figure 1 f). These interactions are important for the epigenetic silencing of tumor suppressor genes, which is an essential role of Kaiso in colon cancer development processes (Lopes et al., 2008).

Regarding epigenetic silencing, the Kaiso protein also acts as a histone-deacetylasedependent transcriptional repressor (Daniel, 2007). The HDAC (histone deacetylase) catalyzes the deacetylation of histones and these changes facilitate more closed chromatin conformation and restrict gene transcription. The HDAC acts as a protein complex with corepressors recruited. Some of them are directly recruited by Kaiso as NCOR1 (nuclear receptor co-repressor 1) (Yoon et al., 2003) and SIN3A (Van Roy \& McCrea, 2005) (Figure 1f).

The information on repression of target genes of the canonical and non-canonical Wnt pathways, associated with cancer (including matrilysin and Wnt11) can lead us to think that the role of Kaiso in the healthy cell is that of a tumor suppressor gene.

\section{Kaiso and tumorigenesis}

Almost all the members of the POZ-ZF family were found to be involved in cancer development. BCL-6 and PLZF are oncoproteins linked to non-Hodgkin's lymphoma and acute promyelocytic leukemia, respectively (Chen et al., 1994; Onizuka et al., 1995). FAZF and ZBTB7 are related to Fanconi's anemia and several other human cancers (Hoatlin et al., 1999; Maeda et al., 2005b; Dai et al., 2002; Pessler et al., 1997). On the other hand, ICH-6 and APM1 are candidate tumor suppressors in various human cancers (Schneider et al., 1997; Albagli, 2003).

Like other members of the subfamily POZ-ZF, the Kaiso protein has been implicated in cancer and the first indirect evidence emerged because the target genes of the Kaiso protein 
(MTA2, MMP2, and siamois CiclinD1) are linked to cell proliferation or metastasis tumor, providing a good indication of the importance, though indirect, of Kaiso in tumorigenesis processes.

More consistent and direct data about the participation of Kaiso in the cancer development process have been recently obtained, when it has been found that Kaiso inhibits activation mediated by $\beta$-catenin of the Mmp7 gene (also known as matrilysin), which is well known for metastatic spread (Spring et al., 2005). Recently another study suggests that Kaiso can regulate TCF/LEF1-activity, via modulating HDAC1 and beta-catenin-complex formation (lioka et al., 2009) (Figure 1f). This shows that Kaiso can directly regulate the signaling pathway of canonical Wnt / $\beta$-catenin widely known for its involvement in human tumors. Other evidence also showed that Kaiso rescues the dorsalization of the mesoderm produced by $\beta$-catenin and siamois in Xenopus laevis (Park et al., 2005). Siamois is a high mobility group (HMG)-box transcription factor that promotes the dorsalization of the mesoderm of amphibians and is a well-known target of the canonical Wnt pathway involving TCF/LEF. The Kaiso overexpression decreases the ability of TCF/LEF to interact with $\beta$-catenin, which implies that Kaiso and TCF/LEF are associated in the nucleus (Van Roy \& McCrea, 2005). Other target genes of canonical Wnt pathway, such as Fos, Myc and CCND1 also appear to be directly regulated by Kaiso. On the other hand, the non-canonical Wnt pathways would also be modulated by Kaiso, at least in Xenopus, where it has been demonstrated that Kaiso depletion directly directly activates the Wnt11 promoter (Kim et al, 2004).

However, there is still controversy regarding the Kaiso's oncogenic or tumor suppressor role. As aforementioned, it is known that matrilysin and Wnt11 are repressed by Kaiso, and, thus, it is believed that it might act as a tumor suppressor (Dai et al., 2009). Nevertheless, Kaiso could also act as a methylation-dependent oncogene, repressing the tumor suppressor gene CDKN2A and providing increased survival of colon cancer cells (Lopes et al., 2008). The epigenetic silencing role of kaiso was approached to produce a depletion of Kaiso (by RNA interference) and an increased expression of the tumor suppressor gene CDKN2 was found, which did not affect the DNA methylation levels. As a result, the colon cancer cells were more susceptible to cell death mediated by chemotherapy (Lopes et al., 2008). It is then possible to assess the importance of kaiso as a possible therapeutical target to improve the efficiency of the current cancer treatments.

\section{Subcellular localization of Kaiso and prognosis of cancer}

As expected for a transcriptional factor, the Kaiso protein is often found in the nucleus of several tumor or non-tumor derived mammalian cell lines (Daniel, 2007). Recent studies using immunohistochemistry analysis of normal and tumor tissue revealed that Kaiso protein is predominantly localized in the cytoplasm of the cell or is totally absent, though (Soubry et al., 2005).

This seems to be unusual because Kaiso has a signal "NLS" highly conserved and required for any protein with nuclear localization. Moreover, Kaiso uses classical nuclear transport mechanisms through interaction with Importin $\alpha / \beta$ nuclear (Kelly et al., 2004). One possible explanation is that Kaiso, like other proteins or factors that normally reside in the cytoplasm, require a post-translational modification, to be targeted and translocated to the cell nucleus. 
However, 2009 data has shown for the first time that the subcellular localization of Kaiso in the cytoplasm of a cell is directly associated with the poor prognosis of patients with lung cancer (non-small cell), and around 85 to 95\% of lung cancers are non-small cell (Dai et al., 2009). Such data shows a direct relationship between the clinical profile of patients with pathological expression of Kaiso. Therefore, evidence of changes in subcellular localization seems to be relevant to the diagnosis and prognosis of various types of human tumors.

\section{Analysis of the subcellular location of Kaiso in Mielode Chronic Leukemia (CML)}

Data obtained by our group in collaboration with the laboratory of stem cells of the Brazilian National Cancer Institute (INCA of Rio de Janeiro), headed by Dr. Eliana Abdelhay, shows the subcellular distribution of Kaiso by immunofluorescence on cell lines K562, used as a model of CML in the blastic phase. As it can be seen in Figure 2a, the expression of Kaiso is clearly cytoplasmic (Cofre, J., personal communications). As expected, cytoplasmic expression is significantly reduced when using the duplex for inhibition of Kaiso (Rnai) 48 hours after transfection (Figure 2b). As a control, we used the $\beta$-tubulin marker and demonstrated that the duplex Kaiso does not modify the expression of this marker after transfection for 48 hours (Figure $2 \mathrm{c}$ and $\mathrm{d}$ ) .
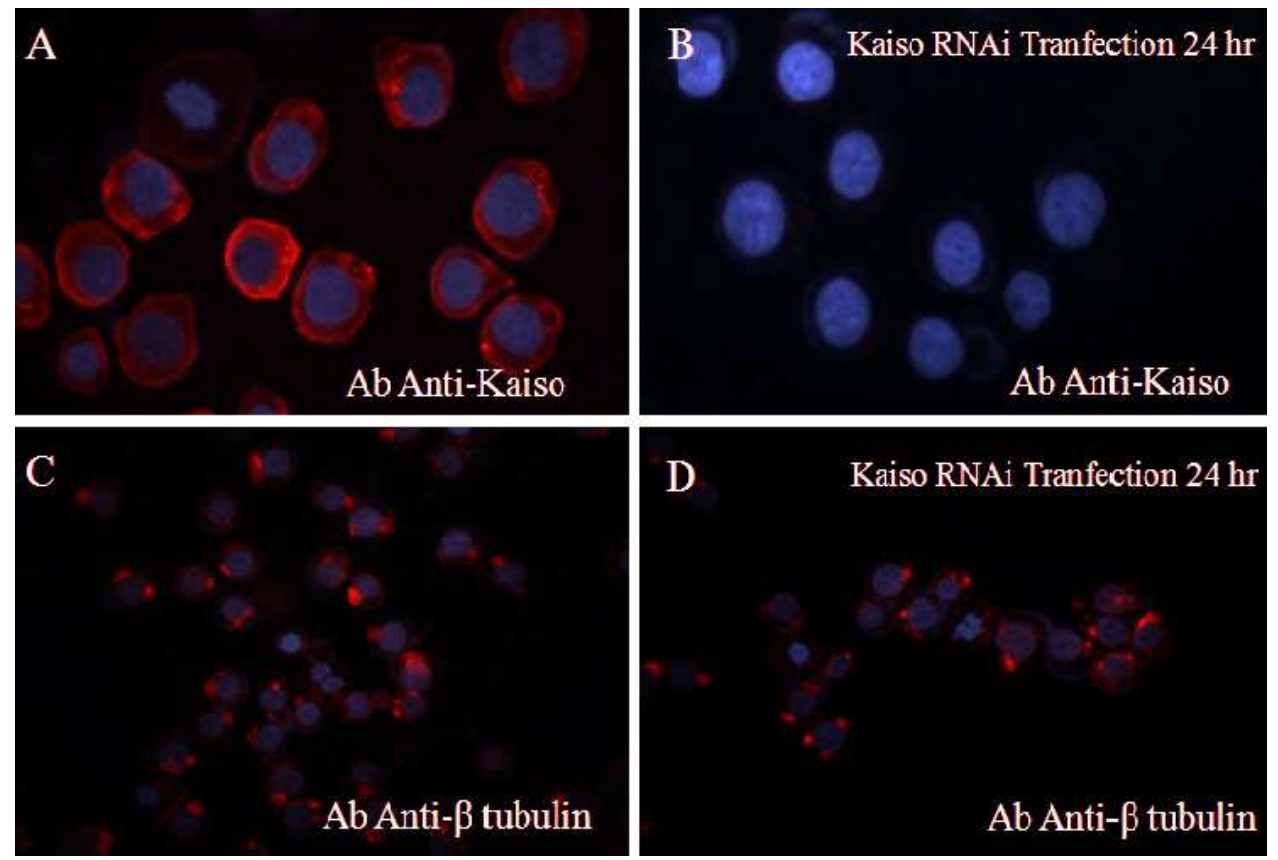

Fig. 2. Immunofluorescence analysis of kaiso expression. A.Kaiso was expressed in the cytoplasm of K562 cells (a human erythroleukemic line). B. siRNA-Kaiso efficiently downregulates cytoplasm expression after 48 hours transfection. As a control, we used the marker beta-tubulin and showed that siRNA-Kaiso does not modify the expression of this marker after 48 hours transfection. 
These results are promising, first because they make it possible to relate the LMC disease to the presence of cytoplasmic Kaiso, and second, because the molecule may have a diagnostic value of clinical interest, not only in LMC, but also in other types of leukemia.

\section{The new view of cellular compartments}

Another noteworthy aspect is that the cellular compartments are currently the object of many discussions in experimental biology, and we are witnessing a reconceptualization of these compartments, which involves the way they are structured and work, as well as their possible relationships with disease development at the cellular level.

It is logical to think that since a cell is in a process of constant division, for any given cell division, the elements in the nucleus and the cytoplasm are mixed, and at this important moment for cellular functioning, the cytoplasmic and nuclear components share the same general compartment that is the cytoplasm of the cell under division. According to this view, there is a very tenuous separation between the cytoplasm and the nucleus of a cell, and the sub compartments generated inside the cytoplasm are what really matters in a cell. Although many scenarios of the separation of specific functions have been detected inside the nucleus (Zhao et al., 2009; Spector \& Lamond, 2011), none of these microenvironments would be maintained in cells in the process of cell division.

These new sub compartments that are important for the understanding of the mechanisms of diseases such as cancer are the networks of endocytic membrane represented by a system of interconnected membranous organelles and endosomes that are responsible for the selection of destination and transport of various types of macromolecules from the extracellular milieu into the cell and within the cell. A recent discovery reveals that the process of endocytosis and endosomes would be crucial for the maintenance of cellular homeostasis, ensuring the compartmentalization of transduction processes of intracellular signals (Scita \& Di Fiore, 2010). It is now widely accepted that systems of endocytic membrane trafficking and intracellular signaling are closely interconnected and endosomes could act as signaling platforms (Hupalowska \& Miaczynska, 2011).

The main endosomal compartment that regulates intracellular signaling processes would be the so-called multivesicular bodies (MVB). It would have a specific role in the sequestration of receptors activated in the membrane that by means of an intracellular mechanism of endocytosis would be placed inside the lumen of the MVB, unable to access the components of intracellular signaling, which would reduce and negatively regulate the signaling pathway of these receptors (Katzmann et al., 2002; Raiborg \& Stenmark, 2009).

Surprisingly, this compartment can also play a role in positive regulation of certain signaling pathways through sequestration of inhibitors (Taelman et al., 2010). Because of its important role in cancer, it is worth mentioning that the Gsk3 and CK1 promoted by the Wnt signaling pathways would be hidden in internal vesicles inside the MVB. The protein complexes involving the Wnt receptor, Gsk3 and CK1 (among others), are then taken inside the lumen of the MVB, separating Gsk3 from their cytoplasmic substrates (Figure 1h). Consequently, in the absence of Gsk3, which is now inside the MVB, $\beta$-catenin would be stabilized in the cytoplasm, translocate into the nucleus and activate transcription.

The endosomal compartments are, thus, a trapping mechanism of enzyme and receptors, and it is believed that it produces the stabilization of many cellular proteins. Coincidentally, 
as discussed in the chapter, proteins as connexin and Kaiso, which are essential for the diagnosis and prognosis of cancer, are always accumulated in the cytoplasm in cancer cells.

This knowledge of endosomal compartments can be of paramount importance for the understanding of the molecular mechanisms by which diseases such as cancer initiate. For example, in the case of specific connexins, the tumor suppressor role could be related to the sequestration of these proteins in MVB during the onset of this tumor. Other related studies have proposed connexins as platforms for sequestering signaling proteins, suggesting that connexins might directly sequester MAPK (Mitogen-Activated Protein Kinase), CDK (Cyclin-dependent kinase), and Src (Proto-oncogene tyrosine-protein kinase) by SH2 and SH3 domains of the carboxyl terminal tail of $\mathrm{Cx} 43$ and, thus, act as a tumor suppressor (Cofre \& Bermudez, 2011).

No studies have shown the association of connexins and endosomal compartments, and yet such studies could help understand the controversy of the expression of connexins in the plasma membrane during early metastasis, which can be related to deregulation mechanisms of cellular physiology of the endocytic compartment.

\section{Future directions}

Therefore, a view focused on subcellular compartments and proteins modulating the epigenome can provide a greater understanding of the biology of malignant cells, as well as improve our approach to cancer treatment. It is known that cancer treatment is dictated by the stage of the disease, and that cancer treatment is more effective during the chronic phase of the disease. Unfortunately, clinical and molecular tests cannot predict disease progression, which can create an obstacle to diagnosis: the inability to identify subtypes of patients most likely to benefit from specific treatment options for specific stages of the disease, which would make it possible to offer a therapy targeted to a given cancer patient.

Finally, the understanding of this new biology of disease progression can provide markers for clinical diagnosis and different approximations for better therapeutic strategies. Also, there is always hope that we'll be able to identify proteins and signaling pathways that may be useful as reliable prognostic markers of the disease and therapeutic targets in the near future.

\section{Acknowledgment}

The author thanks Dr. João Menezes for his contribution in the immunofluorescence of Kaiso, Dra. Eliana Abdelhay and Luciana Pizzatti for critical discussion of the results of cytoplasmic expression of Kaiso. The study was supported by Brazilian National Cancer Institute (INCA of Rio de Janeiro).

\section{References}

Akiyama, T. (2000). Wnt/beta-catenin signaling. Cytokine Growth Factor Rev., Vol.11, No.4, (December 2000), pp.273-282, ISSN 1359-6101.

Albagli, O.; Dhordain, P.; Deweindt, C.; Lecocq, G. \& Leprince, D. (1995). The BTB/ POZ domain: a new protein-protein interaction motif common to DNA and actinbinding proteins. Cell Growth Differ., Vol. 6, No.9, (September 1995), pp.1193-1198, ISSN 1044-9523. 
Bachmann, I.M.; Straume, O.; Puntervoll, H. E.; Kalvenes, M.B. \& Akslen, L. A. (2005). Importance of P-cadherin, beta-catenin, and Wnt5a/frizzled for progression of melanocytic tumors and prognosis in cutaneous melanoma. Clin Cancer Res, vol. 11, No. 24 part 1, (December 2005), pp. 8606-8614, ISSN 1078-0432.

Bardwell, V. J. \& Treisman, R. (1994). The POZ domain: a conserved protein-protein interaction motif. Genes Dev., Vol. 8, No.14, (July 1994), pp.1664-1677, ISSN 08909369.

Bienz, M. (2005).beta-Catenin: a pivot between cell adhesion and Wnt signalling. Curr Biol., vol.15, No.2, (January 2005). pp.R64-R67, ISSN 0960-9822.

Boyle, P. \& Levin, B (2008). World Cancer Report 2008, International Agency for Research on Cancer, ISBN 978-928-3204-23-7, Lyon, France.

Budunova, I. V. \& Williams, G. M. (1994). Cell culture assays for chemicals with tumorpromoting or tumor-inhibiting activity based on the modulation of intercellular communication. Cell Biol Toxicol, Vol. 10, No. 2, (april 1994), pp. 71-116, ISSN 07422091.

Carystinos, G.D.; Bier, A. \& Batist, G. (2001). The role of connexin-mediated cell-cell communication in breast cancer metastasis. J Mammary Gland Biol Neoplasia, Vol.6, No.4, (October 2001), pp. 431-440, ISSN 1083-3021.

Chen, Z.; Guidez, F.; Rousselot, P.; Agadir, A.; Chen, S.J.; Wang, Z.Y.; Degos, L.; Zelent, A.; Waxman, S. \& Chomienne, C. (1994). PLZF-RAR alpha fusion proteins generated from the variant $\mathrm{t}(11 ; 17)(\mathrm{q} 23 ; \mathrm{q} 21)$ translocation in acute promyelocytic leukemia inhibit ligand-dependent transactivation of wildtype retinoic acid receptors. Proc. Natl. Acad. Sci. U. S. A., Vol.91, No.3, (February 1994), pp.1178-1182, ISSN 00278424.

Cho, B.; Lee, H.; Jeong, S.; Bang, Y. J.; Lee, H. J.; Hwang, K. S.; Kim, H. Y.; Lee, Y.S.; Kang, G. H. \& Jeoung, D. I. (2003). Promoter hypomethylation of a novel cancer/testis antigen gene CAGE is correlated with its aberrant expression and is seen in premalignant stage of gastric carcinoma. Biochem Biophys Res Commun., Vol. 307, No. 1, (July 2003), pp. 52-63, ISSN 0006-291X.

Clevers, H. (2006). Wnt/beta-catenin signaling in development and disease. Cell, Vol. 127, No.3, (November 2006), pp. 469-480, ISSN 0092-8674.

Cofre, J. \& Abdelhay, E. (2007). Connexins in the early development of the African clawed frog Xenopus laevis (Amphibia): The role of the connexin43 carboxyl terminal tail in the establishment of the dorso-ventral axis, Genet. Mol. Biol., Vol. 30, No.2, pp. 483-493, ISSN 1415-4757.

Cofre, J. \& Bermudez R. (2011). Conexinas: Canais de Comunicação ou Supressores de Tumores?, In: Discussão de novos paradigmas, Vida Embriologia e Evolução, J. Cofre \& K. Saalfeld (Eds), pp. 175-189, Editoraufsc, ISBN 978-853-2804-93-8, Florianópolis, Brazil.

Collins, T.; Stone, J. R. \& Williams, A. J. (2001). All in the family: the BTB/POZ, KRAB, and SCAN domains. Molecular and cellular biology, vol. 21, No.11, (June 2001), pp.36093615, ISSN 0270-7306.

Crespin, S.; Defamie, N.; Cronier, L. \& Mesnil, M. (2008). Connexins and Carcinogenesis, In: Connexins: A Guide, A. Harris \& D. Locke, (eds.), pp. 529-542, Springer-Verlag, ISBN 978-193-4115-46-6, New York, USA. 
Dabbs, D. J. (2010). Diagnostic Immunohistochemistry: Theranostic and Genomic Applications, Saunders, ISBN 978-141-6057-66-6, Philadelphia, USA.

Dai, M.S.; Chevallier, N.; Stone, S.; Heinrich, M.C.; McConnell, M.; Reuter, T.; Broxmeyer, H.E.; Licht, J.D.; Lu, L. \& Hoatlin, M.E. (2002). The effects of the Fanconi anemia zinc finger (FAZF) on cell cycle, apoptosis, and proliferation are differentiation stage-specific. J. Biol. Chem., Vol.277, No.29, (May 2002), pp. 26327-26334, ISSN 0021-9258.

Dai, S.D.; Wang, Y.; Miao, Y.; Zhao, Y.; Zhang, Y.; Jiang, G.Y.; Zhang, P.X.; Yang, Z.Q. \& Wang, E.H. (2009). Cytoplasmic Kaiso is associated with poor prognosis in nonsmall cell lung cancer. BMC Cancer, Vol.9, pp. 178-189, ISSN 1471-2407.

Daniel, J.M. \& Reynolds, A. B. (1999). The catenin p120(ctn) interacts with Kaiso, a novel BTB/POZ domain zinc finger transcription factor. Mol Cell Biol, vol.19, No.5, (May 1999), pp.3614-3623, ISSN 0270-7306.

Daniel, J.M.; Spring, C.M.; Crawford, H.C.; Reynolds, A.B. \& Baig, A. (2002). The p120(ctn)binding partner Kaiso is a bi-modal DNA-binding protein that recognizes both a sequence-specific consensus and methylated CpG dinucleotides. Nucleic Acids Res., Vol. 30, No.13, (July 2002), pp. 2911-2919, ISSN 1362-4962.

Daniel, J. M. (2007). Dancing in and out of the nucleus p120ctn and the transcription factor kaiso. Biochimica Biophysica Acta, Vol.1773, No.1, (January 2007), pp.59-68, ISSN 0006-3002.

Dang, X.; Doble, B. W. \& Kardami, E. (2003).The carboxy-tail of connexin-43 localizes to the nucleus and inhibits cell growth. Mol Cell Biochem., Vol.242, No.1-2, (January 2003), pp.35-38, ISSN 0300-8177.

Ehrlich, M. (2002). DNA methylation in cancer: too much, but also too little. Oncogene, vol. 21, No. 35, (August 2002), pp. 5400-5413, ISSN 0950-9232.

Esteller, M.; Silva, J. M.; Dominguez, G.; Bonilla, F.; Matias-Guiu, X.; Lerma, E.; Bussaglia, E.; Prat, J.; Harkes, I. C.; Repasky, E. A.; Gabrielson, E.; Schutte, M.; Baylin, S. B. \& Herman, J. G. (2000a). Promoter hypermethylation and BRCA1 inactivation in sporadic breast and ovarian tumors. J Natl Cancer Inst., Vol.92,No.7, (April 2000), pp.564-569, ISSN 0027-8874.

Esteller, M.; Toyota, M.; Sanchez-Cespedes, M.; Capella, G.; Peinado, M. A.; Watkins, D. N.; Issa, J. P.; Sidransky, D.; Baylin, S. B. \& Herman, J. G. (2000b). Inactivation of the DNA repair gene O6-methylguanine-DNA methyltransferase by promoter hypermethylation is associated with $\mathrm{G}$ to $\mathrm{A}$ mutations in K-ras in colorectal tumorigenesis. Cancer Res., Vol. 60, No.9, (May 2000), pp. 2368-2371, ISSN 00085472.

Farmer, P.; Frenk, J.; Knaul, F. M.; Shulman, L. N.; Alleyne, G.; Armstrong, L.; Atun, R.; Blayney, D.; Chen, L.; Feachem, R.; Gospodarowicz, M.; Gralow, J.; Gupta, S.; Langer, A.; Lob-Levyt, J.; Neal, C.; Mbewu, A.; Mired, D.; Piot, P.; Reddy, K. S.; Sachs, J. D.; Sarhan, M. \& Seffrin, J. R. (2010). Expansion of cancer care and control in countries of low and middle income: a call to action. Lancet, vol.376, No. 9747, (August 2010), pp. 1186-1193, ISSN 1474-547X.

Feinberg, A. P. (2008). Epigenetics at the Epicenter of Modern Medicine. JAMA., Vol. 299, No. 11, PP. 1345-1350, ISSN 1538-3598.Galm, O.; Herman, J. G. \& Baylin, S. B. (2006).The fundamental role of epigenetics in hematopoietic malignancies. Blood Rev., vol. 20, No.1, (February 2005), pp. 1-13, ISSN 0268-960X. 
Goodenough, D. A. \& Paul, D. L. (2003). Beyond the gap: functions of unpaired connexon channels.Nat Rev Mol Cell Biol., vol. 4, No.4, (April 2003), pp.285-294, ISSN 14710072

Habas, R.; Kato, Y. \& He, X. (2001). Wnt/Frizzled activation of Rho regulates vertebrate gastrulation and requires a novel Formin homology protein Daam1. Cell, Vol. 107, No.7, (December 2001), pp.843-854, ISSN 0092-8674.

Habas, R.; Dawid, .IB. \& He, X. (2003). Coactivation of Rac and Rho by Wnt/Frizzled signaling is required for vertebrate gastrulation. Genes Dev., Vol. 17, No.2, (January 2003), pp. 295-309, ISSN 0890-9369.

Hake, S.B.; Xiao, A. \& Allis, C. D. (2004. Linking the epigenetic 'language' of covalent histone modifications to cancer. Br J Cancer, vol. 90, No. 4, (February 2004), pp. 761-769, ISSN 0007-0920.

He, H. \& Lehming, N. (2003). Global effects of histone modifications. Brief Funct Genomic Proteomic., Vol. 2, No. 3, (October 2003), pp. 234-243, ISSN 1473-9550.

Herman, J. G.; Latif, F.; Weng, Y.; Lerman, M. I.; Zbar, B.; Liu, S.; Samid, D.; Duan, D. S.; Gnarra, J. R.; Linehan, W. M. \& Baylin, S. B. (1994). Silencing of the VHL tumorsuppressor gene by DNA methylation in renal carcinoma. Proc Natl Acad Sci U S A., Vol. 91, No. 21, (October 1994), pp. 9700-9704, ISSN 0027-8424.

Herman, J.G.; Merlo, A.; Mao, L.; Lapidus, R.G.; Issa, J.P.; Davidson, N.E.; Sidransky, D. \& Baylin, S. B. (1995). Inactivation of the CDKN2/p16/MTS1 gene is frequently associated with aberrant DNA methylation in all common human cancers. Cancer Res., Vol. 55, No. 20, (October 1995), pp. 4525-4530, ISSN 0008-5472.

Herman, J. G.; Umar, A.; Polyak, K.; Graff, J. R.; Ahuja, N.; Issa, J. P.; Markowitz, S.; Willson, J. K.; Hamilton, S. R.; Kinzler, K. W.; Kane, M. F.; Kolodner, R. D.; Vogelstein, B.; Kunkel, T. A. \& Baylin, S. B. Incidence and functional consequences of hMLH1 promoter hypermethylation in colorectal carcinoma. Proc Natl Acad Sci U S A., vol. 95, No. 12, (June 1998), pp. 6870-6875, ISSN 0027-8424.

Hoatlin, M. E.; Zhi, Y.; Ball, H.; Silvey, K.; Melnick, A.; Stone, S.; Arai, S.; Hawe, N.; Owen, G.; Zelent, A. \& Licht. J. D. (1999). A novel BTB/POZ transcriptional repressor protein interacts with the Fanconi Anemia Group C protein and PLZF. Blood,Vol. 94, No.11, (December 1999), pp. 3737-3747, ISSN 0006-4971.

Hochedlinger, K.; Blelloch, R.; Brennan, C.; Yamada, Y.; Kim, M.; Chin, L. \& Jaenisch, R. (2004). Reprogramming of a melanoma genome by nuclear transplantation. Genes Dev., Vol. 18, pp. 1875-1885, ISSN 0890-9369.

Huang, R. P.; Fan, Y.; Hossain, M. Z.; Peng, A.; Zeng, Z. L. \& Boynton, A. L. (1998). Reversion of the neoplastic phenotype of human glioblastoma cells by connexin 43 (Cx43). Cancer Res., vol.58, No.22, (November 1998), pp.5089-5096, ISSN 0008-5472.

Hupalowska, A. \& Miaczynska, M. (2011).The New Faces of Endocytosis in Signaling, In: Traffic,

1.08.2011.,Availablefrom:http:/ / onlinelibrary.wiley.com/doi/10.1111/j.16000854.2 011.01249.x/pdf.

Iioka, H.; Doerner, S.K. \& Tamai, K. (2009). Kaiso is a bimodal modulator for Wnt/betacatenin signaling. FEBS Lett., Vol. 583, No. 4, (January 2009), pp. 627-632, ISSN 1873-3468. 
Jerónimo, C.; Bastian, P. J.; Bjartell, A.; Carbone, G. M.; Catto, J.W.; Clark, S. J.; Henrique, R.; Nelson, W. G. \& Shariat, S.F. (2011). Epigenetics in prostate cancer: biologic and clinical relevance. Eur Urol., vol. 60, No. 4, (June 2011), pp. 753-766, ISSN 1873-7560.

Jones, P. A. \& Baylin, S. B. (2002).The fundamental role of epigenetic events in cancer. Nat Rev Genet., vol. 3, No 6, (June 2002), pp. 415-428, ISSN 1471-0056

Kanczuga-Koda, L.; Sulkowski, S.; Lenczewski, A.; Koda, M.; Wincewicz, A.; Baltaziak, M. \& Sulkowska, M.(2006).Increased expression of connexins 26 and 43 in lymph node metastases of breast cancer. J Clin Pathol, vol. 59, No.4, (April 2006), pp.429-433, ISSN 0021-9746.

Katzmann, D.J.; Odorizzi, G. \& Emr, S.D. (2002). Receptor downregulation and multivesicular-body sorting. Nat Rev Mol Cell Biol, Vol. 3, No.12, (December 2002), pp. 893-905, ISSN 1471-0072.

Kelly, K. F.; Otchere, A. A.; Graham, M. \& Daniel, J. M. (2004). Nuclear import of the BTB/POZ transcriptional regulator Kaiso. J Cell Science, Vol. 117, No.(Pt 25), (December 2004), pp. 6143-6152, ISSN 0021-9533.

Kemler, R. (1993). From cadherins to catenins: cytoplasmic protein interactions and regulation of cell adhesion, Trends Genet, vol. 9, No.9, (September 1993), pp.317321, ISSN 0168-9525.

Kim, S.W.; Park, J.I., Spring, C.M.; Sater, A.K.; Ji, H.; Otchere, A.A.; Daniel, J.M. \& McCrea, P.D. (2004). Non-canonical Wnt signals are modulated by the Kaiso transcriptional repressor and p120-catenin. Nature cell biology, Vol. 6, No.12, (November 2004), pp. 1212-1220, ISSN 1465-7392.

Kim, J.C.; Choi, J.S.; Roh, S.A.; Cho, D.H.; Kim, T.W. \& Kim, Y.S. (2010). Promoter methylation of specific genes is associated with the phenotype and progression of colorectal adenocarcinomas. Ann Surg Oncol., Vol. 17, No. 7, (January 2010), pp. 1767-1776, ISSN 1534-4681.

King, T. J \& Bertram, J. S. (2005). Connexins as targets for cancer chemoprevention and chemotherapy. Biophys Biochim Acta, vol. 1719, No. 1-2, (October 2005), pp.146-160, ISSN 0006-3002.

Kojima, T.; Yamamoto, T.; Lan, M.; Murata, M.; Takano, K.; Go, M.; Ichimiya, S.; Chiba, H. \& Sawada, N. (2004). Inhibition of MAP kinase activity moderates changes in expression and function of Cx32 but not claudin-1 during DNA synthesis in primary cultures of rat hepatocytes. Med Electron Microsc., vol. 37, No.2, (June 2004),pp.101-113, ISSN 0918-4287.

Kouzarides, T. (2007). Chromatin modifications and their function. Cell, Vol. 128, No. 4, (february 2007), pp. 693-705, ISSN 0092-8674.

Laird, D. W.; Fistouris, P.; Batist, G.; Alpert, L.; Huynh, H. T.; Carystinos, G. D. \& AlaouiJamali, M. A. (1999). Deficiency of connexin 43 gap junctions is an independent marker for breast tumors. Cancer Res, vol. 59, No.16, (August 1999), pp. 4104-4110, ISSN 0008-5472.

Lee, S.W.; Tomasetto, C.; Paul, D.; Keyomarsi. K. \& Sager, R. (1992). Transcriptional downregulation of gap-junction proteins blocks junctional communication in human mammary tumor cell lines. J Cell Biol, vol.118, No.5, (September 1992), pp. 12131221, ISSN 0021-9525

Li, L.; Connelly, M.C.; Wetmore, C.; Curran, T. \& Morgan, J. I. (2003). Mouse embryos cloned from brain tumors. Cancer Res., Vol. 63, pp. 2733-2736, ISSN 0008-5472. 
Lichtenstein, P.; Holm, N. V.; Verkasalo, P. K.; Iliadou, A.; Kaprio, J.; Koskenvuo, M.; Pukkala, E.; Skytthe, A. \& Hemminki, K. (2000). Environmental and heritable factors in the causation of cancer-analyses of cohorts of twins from Sweden, Denmark, and Finland. N Engl J Med., vol. 343, No. 2, (July 2000), pp. 78-85, ISSN 0028-4793.

Loewenstein, W. R. (1979). Junctional intercellular communication and the control of growth. Biophys Biochim Acta, vol. 560, No. 1, (February 1979), pp.1-65, ISSN 00063002.

Lopes, E.C.; Valls, E.; Figueroa, M.E.; Mazur, A.; Meng, F.G.; Chiosis, G.; Laird, P.W.; Schreiber-Agus, N.; Greally, J.M.; Prokhortchouk, E. \& Melnick, A. (2008). Kaiso contributes to DNA methylation-dependent silencing of tumor suppressor genes in colon cancer cell lines. Cancer research, Vol.68, No.18, (September 2008), pp. 72587263, ISSN 1538-7445.

Ludwig JA, Weinstein JN. Biomarkers in cancer staging, prognosis and treatment selection. Nat Rev Cancer, Vol. 5, No. 11, (November 2005), pp. 845-856, ISSN 1474-175X.

MacDonald, B.T.; Tamai, K. \& He, X. (2009). Wnt/beta-catenin signaling: components, mechanisms, and diseases. Dev Cell, Vol.17, No.1, (July 2009), pp.9-26, ISSN 18781551.

Maeda, T.; Hobbs, R. M.; Merghoub, T.; Guernah, I.; Zelent, A.; Cordon-Cardo, C.; TeruyaFeldstein, J. \& Pandolfi, P. P. (2005a). Role of the proto-oncogene Pokemon in cellular transformation and ARF repression. Nature, Vol. 433, No 7023, (January 2005), pp.278-285, ISSN 1476-4687.

Maeda, T.; Hobbs, R.M. \& Pandolfi, P.P. (2005b). The transcription factor Pokemon: a new key player in cancer pathogenesis. Cancer Res., Vol.65, No.19, (October 2005), pp. 8575-8578, ISSN 0008-5472.

Marlow, F.; Topczewski, J.; Sepich, D. \& Solnica-Krezel, L. (2002). Zebrafish Rho kinase 2 acts downstream of Wnt11 to mediate cell polarity and effective convergence and extension movements. Curr Biol., Vol.12, No.11, (June 2002), pp. 876-884, ISSN 09609822.

McGarvey KM, Van Neste L, Cope L, Ohm JE, Herman JG, Van Criekinge W, Schuebel KE, Baylin SB. (2008). Defining a chromatin pattern that characterizes DNAhypermethylated genes in colon cancer cells. Cancer Res., vol. 68, No. 14, (July 2008), pp. 5753-5759, ISSN 1538-7445.

McKinnell, R.G.; Deggins, B. A. \& Labat, D.D. (1969). Transplantation of pluripotential nuclei from triploid frog tumors. Science 165: 394-396, ISSN 0036-8075.

Montgomery, E. \& Folpe, A. L. (2005). The diagnostic value of beta-catenin immunohistochemistry, Adv Anat Pathol, vol. 12, No. 6, (November 2005), pp. 350-366, ISSN 1072-4109.

Morin, P. J. (1999). beta-Catenin signaling and cancer. BioEssays, vol. 21, No.12, (December 1999), pp.1021-1030, ISSN 0265-9247.

Muggerud, A.A.; Rønneberg, J. A.; Wärnberg, F.; Botling, J.; Busato, F.; Jovanovic, J.; Solvang, H.; Bukholm, I.; Børresen-Dale, A. L.; Kristensen, V. N.; Sørlie, T. \& Tost, J. (2010). Frequent aberrant DNA methylation of ABCB1, FOXC1, PPP2R2B and PTEN in ductal carcinoma in situ and early invasive breast cancer. Breast Cancer Res., Vol. 12, No. 1, (January 2010), pp. R13, ISSN 1465-542X. 
Nicolson, G. L.; Dulski, K. M. \& Trosko, J. E. (1988). Loss of intercellular junctional communication correlates with metastatic potential in mammary adenocarcinoma cells. Proc Natl Acad Sci USA, vol.85, No.2, (January 1988), pp.473-476, ISSN 00278424.

Nusse, R. (1997). A versatile transcriptional effector of Wingless signaling. Cell, vol.89, No. 3, (may 1997), pp. 321-323, ISSN 0092-8674.

Ocak, S.; Sos, M. L.; Thomas, R. K. \& Massion, P. P. (2009).High-throughput molecular analysis in lung cancer: insights into biology and potential clinical applications. Eur Respir J., Vol. 34,No. 2,(August 2009), pp. 489-506, ISSN 1399-3003.

Oliver, C. \& Jamur, M. C. (2009). Immunocytochemical Methods and Protocols, Humana Press, ISBN 978-158-8294-63-0, New York, USA

Onizuka, T.; Moriyama, M.; Yamochi, T.; Kuroda, T.; Kazama, A.; Kanazawa, N.; Sato, K.; Kato, T.; Ota, H. \& Mori, S. (1995). BCL-6 gene product, a 92- to 98-kD nuclear phosphoprotein, is highly expressed in germinal center B cells and their neoplastic counterparts. Blood, Vol. 86, No.1, (July 1995), pp. 28-37, ISSN 0006-4971.

Park, J. I.; Kim, S.W.; Lyons, J.P.; Ji, H.; Nguyen. T.T.; Cho, K.; Barton, M.C.; Deroo, T.; Vleminckx, K.; Moon, R.T. \& McCrea, P.D. (2005). Kaiso/p120-catenin and $\mathrm{TCF} /$ beta-catenin complexes coordinately regulate canonical Wnt gene targets. Dev Cell, Vol. 8, No.6, (June 2005), pp. 843-854, ISSN 1534-5807.

Park, D.; Choi, S. S. \& Ha, K-S. (2010). Transglutaminase 2: a multi-functional protein in multiple subcellular compartments. Amino Acids, vol.39, No. 3, (february 2010), pp. 619-631, ISNN 1438-2199.

Pessler, F.; Pendergrast, P.S. \& Hernandez, N. (1997). Purification and characterization of FBI-1, a cellular factor that binds to the human immunodeficiency virus type 1 inducer of short transcripts. Mol. Cell. Biol., Vol. 17, No.7, (July 1997), pp. 37863798, ISSN 0270-7306.

Pfeifer, G. P.; Tang, M. \& Denissenko, M. F. (2000). Mutation hotspots and DNA methylation. Curr Top Microbiol Immunol., Vol. 249, pp. 1-19, ISSN 0070-217X.

Polakis, P. (2000). Wnt signaling and cancer, Genes Dev., vol.14, No.15, (August 2000), pp. 1837-1851, ISSN 0890-9369.

Prokhortchouk, A.; Hendrich, B.; Jorgensen, H.; Ruzov, A.; Wilm, M.; Georgiev, G.; Bird, A. \& Prokhortchouk, E. (2001). The p120 catenin partner Kaiso is a DNA methylationdependent transcriptional repressor. Genes Dev., Vol.15, No.13, (July 2001), pp.1613-1618, ISSN 0890-9369.

Raiborg, C. \& Stenmark, H. (2009). The ESCRT machinery in endosomal sorting of ubiquitylated membrane proteins. Nature, Vol.458, No7237, (March 2009), pp.445452, ISSN 1476-4687.

Reuter, S.; Bartelmann, M.; Vogt, M.; Geisen, C.; Napierski, I.; Kahn, T.; Delius, H.; Lichter, P.; Weitz, S.; Korn, B. \& Schwarz, E. (1998). APM-1, a novel human gene, identified by aberrant co-transcription with papillomavirus oncogênese in a cervical carcinoma cell line, encodes a BTB/POZ-zinc finger protein with growth inhibitory activity. EMBO J., Vol. 17, No.1, (January 1998), pp. 215-222, ISSN 0261-4189.

Reynolds, A. B. \& Roczniak-Ferguson, A. (2004). Emerging roles for p120-catenin in cell adhesion and cancer. Oncogene, Vol.23, No.48, (October 2004), pp.7947-7956, ISSN 0950-9232. 
Russo, A. L.; Thiagalingam, A.; Pan, H.; Califano, J.; Cheng, K. H.; Ponte, J. F.; Chinnappan, D.; Nemani, P.; Sidransky, D. \& Thiagalingam, S. (2005). Differential DNA hypermethylation of critical genes mediates the stage-specific tobacco smokeinduced neoplastic progression of lung cancer. Clin Cancer Res., Vol. 11, No. 7, (April 2005), pp. 2466-2470, ISSN 1078-0432.

Sansom, O. J.; Maddison, K. \& Clarke, A. R. (2007). Mechanisms of disease: methyl-binding domain proteins as potential therapeutic targets in cancer. Nat Clin Pract Oncol., vol. 4, No. 5, (May 2007), pp. 305-135, ISNN 1743-4262.

Schneider, A.; Peukert, K.; Eilers, M. \& Hanel, F. (1997). Association of Myc with the zincfinger protein Miz-1 defines a novel pathway for gene regulation by myc. Curr. Top. Microbiol. Immunol., Vol.224, pp.137-146, ISSN 0070-217X.

Scita, G. \& Di Fiore, P.P. (2010). The endocytic matrix. Nature, Vol.463, No.7280, (January 2010), pp.464-473, ISSN 1476-4687.

Seligson, D.B.; Horvath, S.; Shi, T.; Yu, H.; Tze, S.; Grunstein, M. \& Kurdistani, S. K. (2005). Global histone modification patterns predict risk of prostate cancer recurrence. Nature, vol. 435, No 7046, (June 2005), pp. 1262-1266, ISSN 1476-4687.

Seligson, D. B. (2005). The tissue micro-array as a translational research tool for biomarker profiling and validation. Biomarkers, vol. 10, suppl 1, (November 2005), pp. S77-S82, ISSN 1354-750X.

Sinha, P.; Bahadur, S.; Thakar, A.; Matta, A.; Macha, M.; Ralhan, R. \& Gupta, S. D. (2009). Significance of promoter hypermethylation of p16 gene for margin assessment in carcinoma tongue. Head Neck., Vol. 31, No. 11, (November 2009), pp. 1423-1430, ISSN 1097-0347.

Soubry, A.; van Hengel, J.; Parthoens, E.; Colpaert, C.; Van Marck, E.; Waltregny, D.; Reynolds, A.B. \& van Roy, F. (2005). Expression and nuclear location of the transcriptional repressor Kaiso is regulated by the tumor microenvironment. Cancer Res., Vol.65, No.6, (March 2005), pp. 2224 -2233, ISSN 0008-5472.

Spector, D.L. \& Lamond, A.I. (2011). Nuclear speckles. Cold Spring Harb Perspect Biol., Vol. 3 , No. 2, (February 2011), pp. a000646, ISSN 1943-0264.

Spring , C. M.; Kelly, K. F.; O'Kelly, I.; Graham, M.; Crawford, H.C. \& Daniel, J. M. (2005).The catenin p120ctn inhibits Kaiso-mediated transcriptional repression of the beta-catenin/TCF target gene matrilysin. Experimental cell research, Vol.305, No.2, (May 2005), pp.253-265, ISSN 0014-4827.

Stefanska, B.; Huang, J.; Bhattacharyya, B.; Suderman, M.; Hallett, M.; Han, Z. G. \& Szyf, M.(2011). Definition of the landscape of promoter DNA hypomethylation in liver cancer. Cancer Res., vol. 71, No. 17, (July 2011),pp. 5891-5903, ISSN 1538-7445.

Taelman, V.F.; Dobrowolski, R.; Plouhinec, J.L.; Fuentealba, L.C.; Vorwald, P.P.; Gumper, I.; Sabatini, D.D. \& De Robertis, E.M. (2010). Wnt signaling requires sequestration of glycogen synthase kinase 3 inside multivesicular endosomes. Cell, Vol.143, No.7,(December 2010), pp.1136-1148, ISSN 1097-4172.

Taghavi, N.; Biramijamal, F.; Sotoudeh, M.; Khademi, H.; Malekzadeh, R.; Moaven, O.; Memar, B.; A'rabi, A. \& Abbaszadegan, M.R. (2010). p16INK4a hypermethylation and p53, p16 and MDM2 protein expression in esophageal squamous cell carcinoma. BMC Cancer., Vol. 10, (April 2010), pp. 138, ISSN 1471-2407. 
Takahashi, K.; Tanabe, K.; Ohnuki, M.; Narita, M.; Ichisaka, T.; Tomoda, K. \& Yamanaka, S. (2007). Induction of pluripotent stem cells from adult human fibroblasts by defined factors. Cell, Vol. 131, No 5, (November2007), pp. 861-872, ISSN 0092-8674

Tanemura, A.; Terando, A.M.; Sim, M.S.; van Hoesel, A. Q.; de Maat, M. F.; Morton, D.L. \& Hoon, D.S. (2009). CpG island methylator phenotype predicts progression of malignant melanoma. Clin Cancer Res., Vol. 15, No. 5, (February 2009), pp. 18011807, ISSN 1078-0432.

Ueda, K.; Saichi, N.; Takami, S.; Kang, D.; Toyama, A.; Daigo, Y.; Ishikawa, N.; Kohno, N.; Tamura, K.; Shuin, T.; Nakayama, M.; Sato, T. A.; Nakamura,. Y. \& Nakagawa, H. (2011). A comprehensive peptidome profiling technology for the identification of early detection biomarkers for lung adenocarcinoma. PLoS One, Vol. 6, No. 4, (april 2011), pp. e18567, ISSN 1932-6203.

Van Roy, F.M. \& McCrea, P.D. (2005). A role for Kaiso-p120ctn complexes in cancer? Nat Rev Cancer, Vol. 5, No.12, (December 2005), pp. 956-964, ISSN 1474-175X

Veeman, M.T.; Axelrod, J.D. \& Moon, R.T. (2003). A second canon. Functions and mechanisms of $\beta$-catenin-independent Wnt signaling. Dev Cell, Vol. 5, No.3, (Setember 2003), pp. 367-377, ISSN 1534-5807.

Vinken, M.; Vanhaecke, T.; Papeleu, P.; Snykers, S.; Henkens, T. \& Rogiers, V. (2006). Connexins and their channels in cell growth and cell death. Cell Signal, vol. 18, No.5, (September 2005), pp.592-600, ISSN 0898-6568.

Wales, M. M.; Biel, M. A.; Deiry, W. E.; Nelkin, B. D.; Issa, J.-P.; Cavenee, W. K.; Kuerbitz, S. J. \& Baylin, S. B. (1995). p53 activates expression of HIC-1, a new candidate tumor suppressor gene on 17p13.3. Nat. Med., Vol.1, No.6, (June 1995), pp. 570-576, ISSN 1078-8956.

Wallingford, J.B.; Fraser, S.E. \& Harland, R.M. (2002). Convergent extension: the molecular control of polarized cell movement during embryonic development. Dev Cell, Vol.2, No.6, (June 2002), pp.695-706, ISSN 1534-5807.

Yamasaki, H. \& Naus, C. C. (1996). Role of connexin genes in growth control. Carcinogenesis, Vol.17, No.6, (June 1996),pp.1199-1213, ISSN 0143-3334.

Yoon, J.H.; Smith, L.E.; Feng, Z.; Tang, M.; Lee, C.S. \& Pfeifer, G.P. (2001). Methylated CpG dinucleotides are the preferential targets for G-to-T transversion mutations induced by benzo[a]pyrene diol epoxide in mammalian cells: similarities with the p53 mutation spectrum in smoking-associated lung cancers. Cancer Res., Vol. 61, No. 19, (October 2001), pp. 7110-7117, ISSN 0008-5472.

Yoon, H. G.; Chan, D. W.; Reynolds, A. B.; Qin, J. \& Wong, J. M. (2003). N-CoR mediates DNA methylation-dependent repression through a methyl CpG binding protein Kaiso. Mol. Cell, Vol.12, No.3, (September 2003), pp. 723-734, ISSN 1097-2765.

Yoshimura, T.; Nagahara, M.; Kuo, C.; Turner, R. R.; Soon-Shiong, P. \& Hoon, D. S. (2011). Lymphovascular invasion of colorectal cancer is correlated to SPARC expression in the tumor stromal microenvironment. Epigenetics, Vol. 6 No. 8, (august 2011), pp.1001-1011, ISSN 1559-2308.

Zhao, R.; Bodnar, M.S. \& Spector, D.L. (2009). Nuclear neighborhoods and gene expression. Curr Opin Genet Dev., Vol. 19, No.2, (March 2009), pp.172-179, ISSN 1879-0380. 
Zhang, Y. W.; Morita, I.; Ikeda, M.; Ma, K. W. \& Murota, S. (2001). Connexin43 suppresses proliferation of osteosarcoma U2OS cells through post-transcriptional regulation of p27. Oncogene, vol.20, No.31, (July 2001), pp. 4138-4149, ISSN 0950-9232.

Ziech, D.; Franco, R.; Pappa, A.; Malamou-Mitsi, V.; Georgakila, S.; Georgakilas, A. G. \& Panayiotidis, M.I. (2010). The role of epigenetics in environmental and occupational carcinogenesis. Chem Biol Interact., Vol. 188, No. 2, (July 2010), pp. 340-349, ISSN $1872-7786$. 


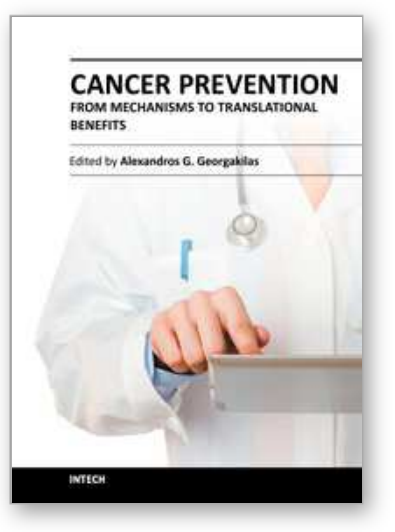

\author{
Cancer Prevention - From Mechanisms to Translational Benefits \\ Edited by Dr. Alexandros G. Georgakilas
}

ISBN 978-953-51-0547-3

Hard cover, 476 pages

Publisher InTech

Published online 20, April, 2012

Published in print edition April, 2012

This unique synthesis of chapters from top experts in their fields targets the unique and significant area of cancer prevention for different types of cancers. Perspective readers are invited to go through novel ideas and current developments in the field of molecular mechanisms for cancer prevention, epidemiological studies, antioxidant therapies and diets, as well as clinical aspects and new advances in prognosis and avoidance of cancer. The primary target audience for the book includes PhD students, researchers, biologists, medical doctors and professionals who are interested in mechanistic studies on cancer prevention and translational benefits for optimized cancer treatment.

\title{
How to reference
}

In order to correctly reference this scholarly work, feel free to copy and paste the following:

Jaime Cofre (2012). Kaiso and Prognosis of Cancer in the Current Epigenetic Paradigm, Cancer Prevention From Mechanisms to Translational Benefits, Dr. Alexandros G. Georgakilas (Ed.), ISBN: 978-953-51-0547-3, InTech, Available from: http://www.intechopen.com/books/cancer-prevention-from-mechanisms-totranslational-benefits/kaiso-and-prognosis-of-cancer-in-the-current-epigenetic-paradigm

\section{INTECH}

open science | open minds

\section{InTech Europe}

University Campus STeP Ri Slavka Krautzeka 83/A 51000 Rijeka, Croatia Phone: +385 (51) 770447

Fax: +385 (51) 686166 www.intechopen.com

\section{InTech China}

Unit 405, Office Block, Hotel Equatorial Shanghai No.65, Yan An Road (West), Shanghai, 200040, China 中国上海市延安西路65号上海国际贵都大饭店办公楼405单元 Phone: +86-21-62489820

Fax: +86-21-62489821 
(C) 2012 The Author(s). Licensee IntechOpen. This is an open access article distributed under the terms of the Creative Commons Attribution 3.0 License, which permits unrestricted use, distribution, and reproduction in any medium, provided the original work is properly cited. 